Escritura y Pensamiento 20-24(40-48), 2021, 451-455

\title{
Patrón Candela, Germán. El proceso Vallejo. Lima: Fondo Editorial del Poder Judicial, 2020, pp. 522.
}

Hacia fines de 2020, se presentaron distintos conflictos sociales y políticos en medio de una de las mayores pandemias del mundo, que continúa ahondando una crisis general. Por ejemplo, sobrevinieron manifestaciones a mediados de noviembre en contra de la asunción presidencial de Manuel Merino, que motivaron su renuncia. Dos personas murieron y varios fueron apresados. Dos semanas después, en diciembre, la Dircote ejecutaba la "Operación Olimpo", en la que se detuvo a distintas personas (estudiantes, trabajadores y jubilados), acusadas de pertenecer a grupos terroristas. Hoy, muchos siguen encarcelados sin pruebas concluyentes. Ese mismo mes, en Ica, los trabajadores del agro se movilizaron para reclamar mejoras laborales, debido a que - como denunciaban- estaban trabajando en condiciones paupérrimas. Dos muertos, diversos heridos y más arrestados fue el saldo. En ese "escenario de supervivencia”, se reeditó El proceso Vallejo, de Germán Patrón, libro que expone la acusación, captura, liberación, persecución y reivindicación de César Abraham Vallejo Mendoza (18921938), el más grande poeta peruano.

Esta tercera edición se presenta en el año en que "rememoramos el centenario de la injusta prisión de Vallejo" (p. LXIV), que duró cerca de cuatro meses, del 6 de noviembre de 1920 al 26 de febrero de 1921. Pero no solo debe verse como una curiosidad editorial, sino como un texto obligatorio para los lectores interesados en la vida y obra del vate santiaguino. En 
medio de la coyuntura descrita, también se celebró el coloquio "Centenario del Proceso Judicial Seguido contra el Poeta César Vallejo" (7, 14, 21 y 28 de noviembre de 2020), que invitaba a los investigadores a presentar trabajos relacionados con el oscuro episodio de la vida del autor de Los heraldos negros (1918). Así, El proceso Vallejo resulta ser una obra pionera en ese campo, pues, además de describir eventos biográficos de dicho periodo, incorpora argumentos judiciales, literarios e históricos para trazar un panorama inédito que atraviesa el periplo vital y creativo del defendido. Seamos más detallados.

Esta nueva publicación, que se suma a la de 1992 y la de 2015, contiene un "Prólogo a la tercera edición" (pp. XV-XX), su "Presentación" (pp. XXI-XXIII), su "Estudio introductorio" (pp. XXV-LIV), los "Criterios de edición" (pp. LV-LXV) y el texto de Patrón Candela, que incluye a su vez un "Prólogo", una "Presentación" y siete capítulos. Respecto a la edición de 2020, cabe resaltar la labor "filológica de reconstructiva cirugía editorial” (p. LIX), resaltada por la editora, Gladys Flores, que busca subsanar los errores de la primera y los descuidos de la segunda. Actualizando los datos bibliográficos e incorporando documentos del proceso seguido a Vallejo, permite una lectura más completa del caso expuesto por el autor. Es necesario, por otro lado, resaltar las limitaciones del "Estudio introductorio" que, en gran medida, es una suerte de recapitulación abrupta de lo descrito por Patrón, a pesar de que se sugiere cierto sesgo en su investigación y su confianza candorosa (p. LII) en algunos biógrafos y estudiosos del autor de Trilce (1922). Detengámonos en el texto principal.

El proceso Vallejo inicia con un extenso prólogo a cargo de Héctor Centurión Vallejo, quien, más que comentar la obra, crea un ambiente geográfico, histórico e intelectual que rodea al poeta norteño desde pequeño. Para él, resulta imprescindible demostrar, a partir de un montaje panorámico, la imposibilidad de que César Vallejo haya podido cometer actos vandálicos, ya que su formación académica y vivencial implica una rectitud 
moral (p. 22). Así, reconstruye - parcialmente- la historia de Trujillo con sus actores principales y las instituciones educativas. Eso le permite constatar las influencias, las enseñanzas y las prácticas del niño y joven César Abraham. Así mismo, inscribe el hecho particular del vate dentro de lo padecido por la mayoría de intelectuales de la misma región, en esa época o años después: acusaciones, persecuciones, encarcelamientos o destierros. E invierte las consecuencias: mientras muchos de ellos hoy son recordados por sus diferentes aportes a la cultura peruana, sus acusadores, prácticamente, han sido olvidados. Un ejemplar caso de justicia histórica.

En la "Presentación" se pueden destacar tres variables: la labor de investigador que recorre "tenebrosos sótanos" (p. 58) para obtener los viejos archivos; la intención crítica interdisciplinaria al proponerse un estudio "crítico-jurídico-literario" (p. 58) y, finalmente, la capacidad de ordenamiento que anuda los documentos legales, los poemas y la crítica sobre Vallejo (pp. 60-61). Más allá del alcance o no de los objetivos, el autor funda una ruta de exégesis para abordar la problemática de la creación de varios poemas que tienen como base una experiencia trágica, como la del encierro injusto. Luego de estas precisiones, articula las experiencias del poeta peruano y la de Picasso, pintor español, ya que ambos recibieron el brutal impacto de lo que fue la Guerra Civil española (1936-1939).

El Capítulo I, que sirve de "Introducción", sigue una lógica parecida a la del prologuista de la edición de 1992. Pero, al ambiente geográfico y cultural, se añade a Vallejo como memoria influyente en intelectuales de la segunda mitad del siglo XX. Asimismo, el comentario de distintos poemas de Los heraldos negros y Trilce, que se articulan al discurso bajo una directriz biografista. Y, además, los homenajes preliminares que desembocarán en la búsqueda, análisis y exposición del expediente judicial seguido al poeta. Del mismo modo, se encarga de referir los hechos previos a la acusación por disturbios y daños a ter- 
ceros, pues el poeta llegó a Santiago de Chuco en medio de celebraciones patronales y con el dolor por la pérdida de su madre.

En el segundo capítulo, se pasará a la revisión de los documentos legales para reconstruir los eventos del 1 de agosto de 1920 , en los cuales Vallejo se vio envuelto, parcialmente, y por los cuales fue denunciado. En el siguiente, elabora un mapa de recorridos del vate previos a su encierro y sus padecimientos ya en prisión. Subrayamos la lectura que Patrón realiza sobre los poemas que, según sus críticos, fueron escritos en su estadía en la cárcel. Aclara, reformula, propone y concluye varios versos que, de otra manera, quedaría en la oscuridad semántica por los experimentos lingüísticos propios de las vanguardias y del temperamento del autor de El tungsteno. Una conclusión errónea sería acusar de biografismo al autor, puesto que en ningún momento desautoriza a otros exégetas (salvo en el caso de Neale-Silva y su interpretación de “Trilce XXV" [pp. 351-357]), sino que menciona esas lecturas como válidas. Su intención, en realidad, es mostrar cómo esos poemas, que impresionan y causan emoción, surgen del hundimiento anímico y moral de una persona que había sido acusada injustamente.

Los siguientes capítulos se encargan de revelar el proceso de liberación con ayuda de su abogado y otros intelectuales (Capítulo IV), la formalización sospechosa de su caso, cargada de diversas contradicciones (Capítulo V), y el éxodo del poeta hacia Europa por el temor de volver a prisión (Capítulo VI). En el epílogo (Capítulo VII), se presentan las recapitulaciones y resúmenes de todo lo expuesto por el autor en lo concerniente al caso Vallejo, concluyendo que se ha cometido en agravio del poeta "reiterado delito de prevaricato y de abuso de autoridad y denegación y retardo de justicia" (p. 502). Así, El proceso Vallejo es en un extenso alegato en favor de la reivindicación de la memoria del vate, quien fue denunciado, encarcelado y perseguido, y que todo esto originó su errancia por Europa, lo que causaría el deterioro de su estado físico hasta su muerte, en 1938. 
Iniciamos nuestra exposición con los casos, entre mucho otros, de encierro o persecución de personas solo en 2020. ¿Cuántas más padecieron lo mismo antes y después del caso de César Vallejo? Es imposible determinarlo y tratar de hacerse una idea podría resultar escalofriante. Sirva este texto como ejemplo de la paradoja de nuestro sistema legal: pues en el ámbito donde uno debería buscar justicia se suele hallar lo contrario. De ahí que secundamos la idea de que Vallejo "sufrió como sufre el pueblo peruano, en la ignominia de un proceso de grosera mistificación" (p. 184) y que, por eso, su protesta debido a su arbitrario encarcelamiento, que nos llega por intermedio de Patrón Candela, "es la que formularía cualquier hombre maltratado por el encierro en la cárcel inmunda y por el procedimiento de jueces ignorantes y de mala fe" (p. 250). (Luis Eduardo Velásquez Ccosi) 